\title{
Infiltrating Bladder Urothelial Carcinoma, Clear Cell Variant
}

National Cancer Institute

\section{Source}

National Cancer Institute. Infiltrating Bladder Urothelial Carcinoma, Clear Cell Variant. NCI Thesaurus. Code C39827.

An invasive transitional cell carcinoma of the bladder characterized by the presence of clear cells. 